Reprod. Nutr. Dévelop., 1984, 24 (2), 127-136.

The modulatory effect in vitro of oestradiol-17 $\beta$, testosterone or cortisol on the output of $17 \alpha$-hydroxy-20 $\beta$-dihydroprogesterone by rainbow trout (Salmo gairdneri) ovarian follicles stimulated by the maturational gonadotropin s-GtH.

\author{
B. JALABERT, A. FOSTIER
}

with the technical assistance of Odile MARCUZZI and Micheline HEYDORFF

Laboratoire de Physiologie des Poissons, I.N.R.A., Campus de Beàulieu, 35042 Rennes Cedex, France.

Summary. The effect of oestradiol-17 $\beta$, testosterone or cortisol in the incubation medium $(1 \mu \mathrm{g} / \mathrm{ml})$ upon s-GtH-induced $17 \alpha$-hydroxy-20 $\beta$-dihydroprogesterone $\quad(17 \alpha, 20 \beta-\mathrm{OH}-\mathrm{P})$ secretion by trout ovarian follicles in vitro was investigated in order to elucidate by which mechanism these steroids were able to modulate s-GtH efficiency on the maturation of intrafollicular oocytes with the germinal vesicle initially in subperipheral position.

Oestradiol inhibited significantly $17 \alpha, 20 \beta-\mathrm{OH}-\mathrm{P}$ output by the follicles of the two females tested at all doses of $\mathrm{s}-\mathrm{GtH}(3.91-500 \mathrm{ng} / \mathrm{ml})$.

Testosterone and cortisol stimulated significantly $17 \alpha, 20 \beta-\mathrm{OH}-\mathrm{P}$ output by follicles only at doses of $\mathrm{GtH}$ below $31.25 \mathrm{ng} / \mathrm{ml}$.

The physiological relevance and implications of these findings have been discussed.

\title{
Introduction.
}

In salmonids, the ultimate control of oocyte maturation (resumption of meiosis) by the maturational gonadotropin $(\mathrm{GtH})$ appears to be mediated through follicular synthesis of $17 \alpha$-hydroxy-20 $\beta$-dihydroprogesterone $(17 \alpha, 20 \beta-\mathrm{OH}$-P) (for review see Jalabert, 1976 ; Fostier and Jalabert, 1982 ; Goetz, 1983). 17 $\alpha, 20 \beta$ $\mathrm{OH}-\mathrm{P}$, the most potent steroid-inducer of oocyte maturation tested in vitro so far (Fostier, Jalabert and Terqui, 1973 ; Jalabert, 1976 ; Duffey and Goetz, 1980 ; Nagahama, Kagawa and Tashiro 1980), is produced in vitro by the preovulatory follicle in response to $\mathrm{GtH}$ (Fostier et al., 1981 ; Suzuki, Tamaoki and Hirose, 1981 ; Suzuki, Nagahama and Tamaoki, 1981 ; Theofan, 1981). The preovulatory follicle can also produce androgens, oestrogens and corticosteroids (Suzuki, Tamaoki and Hirose, 1981 ; Theofan, 1981 ; Zohar, 1982). From observation of trout plasma profiles of oestradiol- $17 \beta$ and testosterone before ovulation (Fostier et al., 1978; Fostier and Jalabert, 1982; Scott and Baynes, 1982 ; Scott, 
Sumpter and Hardiman, 1983) and considering plasma cortisol levels in maturing female trout (Pickering and Christie, 1981), it is clear that these steroids are present at noticeable levels in blood prior to the surge of $17 \alpha, 20 \beta-\mathrm{OH}-\mathrm{P}$. From in vitro experiments, it was found that oestradiol lowers the efficiency of GtH to induce intrafollicular oocyte maturation, whereas testosterone and cortisol enhance this efficiency (Jalabert, 1975). Similar effects have been shown in the amago salmon with testosterone and deoxycorticosterone, but not with oestradiol-17 $\beta$ (Young, Kagawa and Nagahama, 1982). Since oestradiol-17 $\beta$ and testosterone do not significantly modify the maturational efficiency in vitro of $17 \alpha, 20 \beta-\mathrm{OH}-\mathrm{P}$ (Jalabert, 1975), it can be hypothesized that they interfere mostly in the mechanism of GtH action, at the follicular level. Concerning cortisol, which exhibits a positive synergy with either $\mathrm{GtH}$ or $17 \alpha, 20 \beta-\mathrm{OH}-\mathrm{P}$ in respect to intrafollicular maturation, it may interact with either the $\mathrm{GtH}$ action mechanism in the follicular envelopes or with the $17 \alpha, 20 \beta-\mathrm{OH}-\mathrm{P}$ action mechanism at the oocyte level.

The aim of the present study was to determine if oestradiol, cortisol or testosterone could modulate the secretion of $17 \alpha, 20 \beta-\mathrm{OH}-\mathrm{P}$ induced in vitro in rainbow trout follicles by the maturational gonadotropin $\mathrm{s}-\mathrm{GtH}$.

\section{Material and methods.}

Animals. - Two 3-year old female rainbow trout (Salmo gairdneri) weighing about $1.5 \mathrm{~kg}$ were used. They were taken from a lot of " hivernal strain " trout (spawning in November-December) reared in the Gournay/Aronde (Oise) fish farm and acclimated for 2 months in the recycled water unit of the laboratory at $12{ }^{\circ} \mathrm{C}$ where they were fed with commercial pellets. During the "spawning period ", all the fish were anesthetized once weekly by a $0.3 \%$ solution of 2-phenoxy-ethanol in water in order to check the oocyte stage that was determined by examining a few follicles squeezed out by abdominal stripping. The two females were selected when they exhibited oocytes with the germinal vesicle (GV) in subperipheral condition (Jalabert et al., 1976). They were killed by a knock on the head, then completely bled out by puncture in the caudal vein ; the ovaries were removed for subsequent dissection.

Incubations. - The ovaries were entirely dissected into small clusters of 2 to 6 follicles within the interstitial tissue. Incubations were carried out at $12.5^{\circ}$ for $72 \mathrm{~h}$ under a renewed atmosphere of $50 \% \mathrm{~N}_{2}-50 \% \mathrm{O}_{2}$ in vials containing 25 follicles per $4 \mathrm{ml}$ of trout balanced salt solution (TBSS: $\mathrm{NaCl} 133 \mathrm{mM} ; \mathrm{KCl}$ $3.1 \mathrm{mM} ; \mathrm{MgSO}_{4} 0.3 \mathrm{mM} ; \mathrm{MgCl}_{2} 1 \mathrm{mM}$; $\mathrm{CaCl}_{2} 3.4 \mathrm{mM}$; glucose : $1 \mathrm{~g} / \mathrm{l}$; penicillin ; 100000 units/l, streptomycin sulfate : $100 \mathrm{mg} / \mathrm{l}$ (DIFCO)), buffered by Hepes- $\mathrm{NaOH} 0.04 \mathrm{M}$ at $\mathrm{pH}$ 8. At the beginning of incubation we put into each vial : (1) either $10 \mu \mathrm{l}$ of ethanol as a control or $10 \mu \mathrm{l}$ of ethanol containing oestradiol, testosterone or cortisol $(400 \mu \mathrm{g} / \mathrm{ml}$ ethanol) to obtain a final steroid concentration of $1 \mu \mathrm{g} / \mathrm{ml}$ and (2) $100 \mu \mathrm{l}$ of TBSS as a control or $100 \mu \mathrm{l}$ of TBSS containing the appropriate dose of salmon gonadotropin s-GtH. Nine doses of s$\mathrm{GtH}$ were used to give final concentrations ranging from $3.9 \mathrm{ng} / \mathrm{ml}$ to $500 \mathrm{ng} / \mathrm{ml}$. 
Each hormonal combination was repeated twice for female 1 and three times for female 2. After $48 \mathrm{~h}$ and $72 \mathrm{~h}, 1 \mathrm{ml}$ of incubation medium was taken from each vial and frozen at $-20{ }^{\circ} \mathrm{C}$ until subsequent radioimmunoassay of the amount of $17 \alpha, 20 \beta-\mathrm{OH}-\mathrm{P}$ secreted. After $72 \mathrm{~h}$, the number of mature oocytes was counted in each vial.

Hormones. - The pure salmon maturational gonadotropin s-GtH was prepared in the laboratory by B. Breton, as described by Breton, Prunet and Reinaud (1978). The steroids were purchased from Steraloids (USA).

Bioassay of $s-G t H$. - The median efficient dose of $\mathrm{s}-\mathrm{GtH}$, alone or in combination with steroids, was calculated from the proportion of mature oocytes in each vial, as described by Jalabert, Breton and Billard (1974).

Radioimmunoassay of $17 \alpha, 20 \beta-\mathrm{OH}-\mathrm{P}$. - RIA was performed as described by Fostier et al. (1981). Cross-reactivities, expressed as the ratio of the mass of $17 \alpha, 20 \beta-\mathrm{OH}-\mathrm{P}$ to the mass of steroid required to decrease the bound level of the tracer to half its value without competitor, were : $2 \%$ for $20 \beta$-dihydroprogesterone and $1 \%$ for $17 \alpha$-hydroxy-20 $\alpha$-dihydroprogesterone. Furthermore, $100 \mathrm{ng}$ of progesterone, pregnenolone, $17 \alpha$-hydroprogesterone, $20 \alpha$-dihydroprogesterone, $5 \beta$-pregnan-3 $\alpha, 17 \alpha$-diol-20-one, cortisone, $20 \beta$-dihydrocortisone or deoxycorticosterone competed less with the tracer than $0.020 \mathrm{ng}$ of $17 \alpha, 20 \beta-\mathrm{OH}-\mathrm{P}$. There was no competition with as much as $100 \mathrm{ng}$ of $5 \beta$-pregnan- $3 \alpha$-ol-20 one, $5 \beta$-pregnan-17 $\alpha$-ol-3,20-dione, 11-ketoprogesterone, $11 \alpha$-hydroprogesterone, testosterone, 11-ketosterone, oestradiol-17 $\beta$, oestrone, cortisol, corticosterone. A plasma pool was assayed repeatedly to estimate measurement variability. The coefficients of variation were $7.7 \%(n=14)$ for the assay of the total of the samples from female 1 and $10.0 \%(n=36)$ for the total of the samples from female 2.

Statistical analysis. - The secretion curves $(17 \alpha, 20 \beta-\mathrm{OH}-\mathrm{P}$ secreted in the medium after 48 or $72 \mathrm{~h}$ as a' function of s-GtH concentration) of steroid treatments and control were compared using covariance analysis applied to the linear portions of curves.

\section{Results.}

Figures 1 and 2 show the effect of oestradiol, testosterone or cortisol on the secretion of $17 \alpha, 20 \beta-\mathrm{OH}-\mathrm{P}$ by the follicles of female 1 after $48 \mathrm{~h}$ and $72 \mathrm{~h}$, respectively, of incubation in vitro under the action of increasing concentrations of s-GtH. In comparison with the control, oestradiol treatment exhibited a clear inhibitory effect (particularly significant for the higher doses of $\mathrm{s}-\mathrm{GtH}$ ) in the range of 31.25 to $500 \mathrm{ng} / \mathrm{ml}$ (table 1). On the other hand, the presence of testosterone or cortisol had a stimulatory action only on the lower doses of $\mathrm{s}-\mathrm{GtH}$ in the range of 3.91 to $31.25 \mathrm{ng} / \mathrm{ml}$. Whereas the increase in the production of $17 \alpha, 20 \beta-\mathrm{OH}-\mathrm{P}$ in the presence of cortisol was already significant after only 48-h incubation, the favourable effect of testosterone needed $72 \mathrm{~h}$ to become significant (table 1 ). 


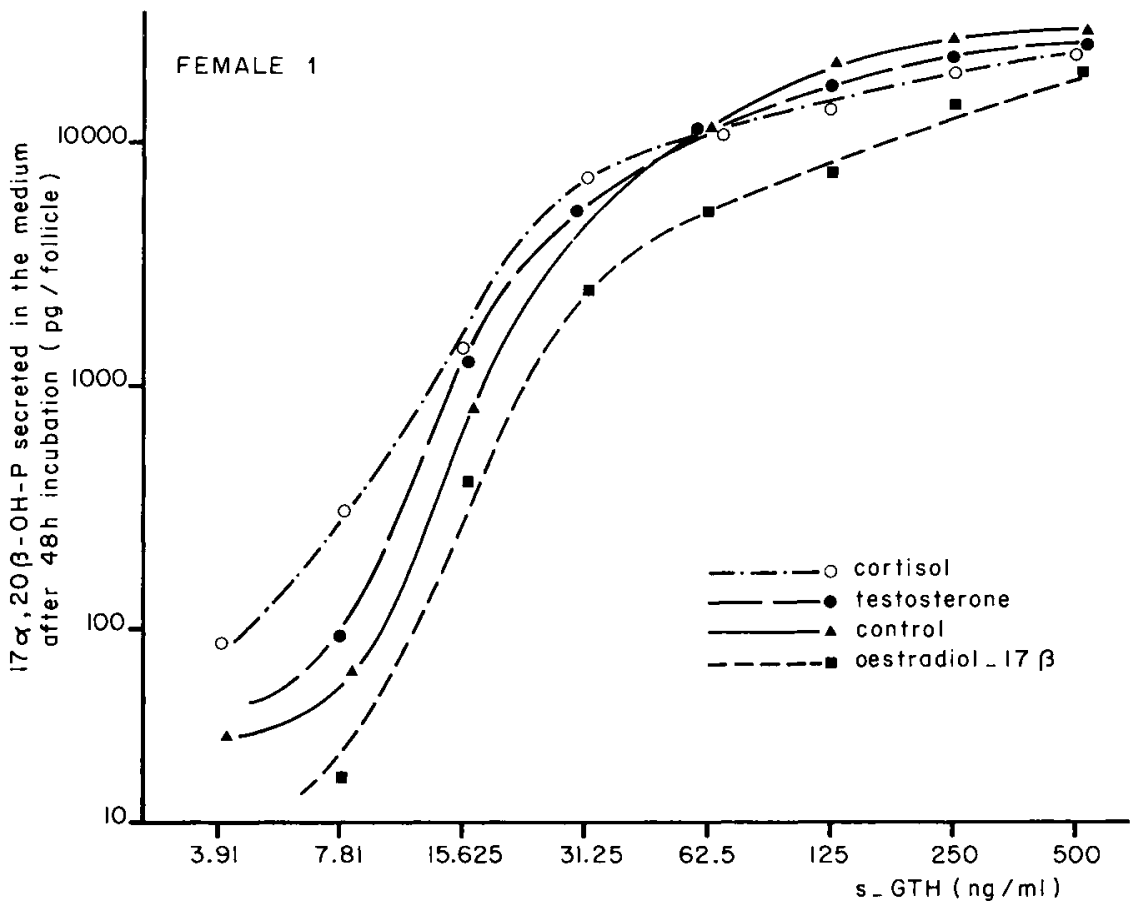

FIG. 1. - Amount of $17 \alpha, 20 \beta-O H-P$ secreted into the incubation medium after $48-h$ incubation as a function of the concentration of $\mathrm{s}-\mathrm{GtH}$ in the medium (female 1).

\section{TABLE 1}

(Female 1) : A comparison of the secretion curves $(17 \alpha, 20 \beta-\mathrm{OH}-\mathrm{P}$ as a function of $\mathrm{GtH}$ concentration) of steroid treatments and control.

\begin{tabular}{|c|c|c|c|c|c|c|}
\hline & \multicolumn{5}{|c|}{ Concentration of s-GtH $(\mathrm{ng} / \mathrm{ml})$} \\
\hline & & 3.91 & 7.81 & 15.62 & 31.25 & 500 \\
\hline \multirow{2}{*}{ Oestradiol-17 $\beta$} & $48 \mathrm{~h}$ & \multicolumn{3}{|c|}{ inhibition (NS) } & \multicolumn{2}{|c|}{ inhibition $(* * *)$} \\
\hline & $72 \mathrm{~h}$ & \multicolumn{3}{|c|}{ inhibition (NS) } & inhib & \\
\hline \multirow{2}{*}{ Testosterone } & $48 \mathrm{~h}$ & \multicolumn{3}{|c|}{ stimulation (NS) } & & \\
\hline & $72 \mathrm{~h}$ & \multicolumn{3}{|c|}{ stimulation $\left({ }^{*}\right)$} & & \\
\hline \multirow{2}{*}{ Cortisol } & $48 \mathrm{~h}$ & \multicolumn{3}{|c|}{ stimulation $(*)$} & & \\
\hline & $72 \mathrm{~h}$ & \multicolumn{3}{|c|}{ stimulation $\left({ }^{* * *}\right)$} & & \\
\hline
\end{tabular}

Significance of the difference : NS $=$ not significant $;{ }^{*},{ }^{* *},{ }^{* *}=$ significant at the probability levels of $0.05,0.01,0.001$, respectively. 


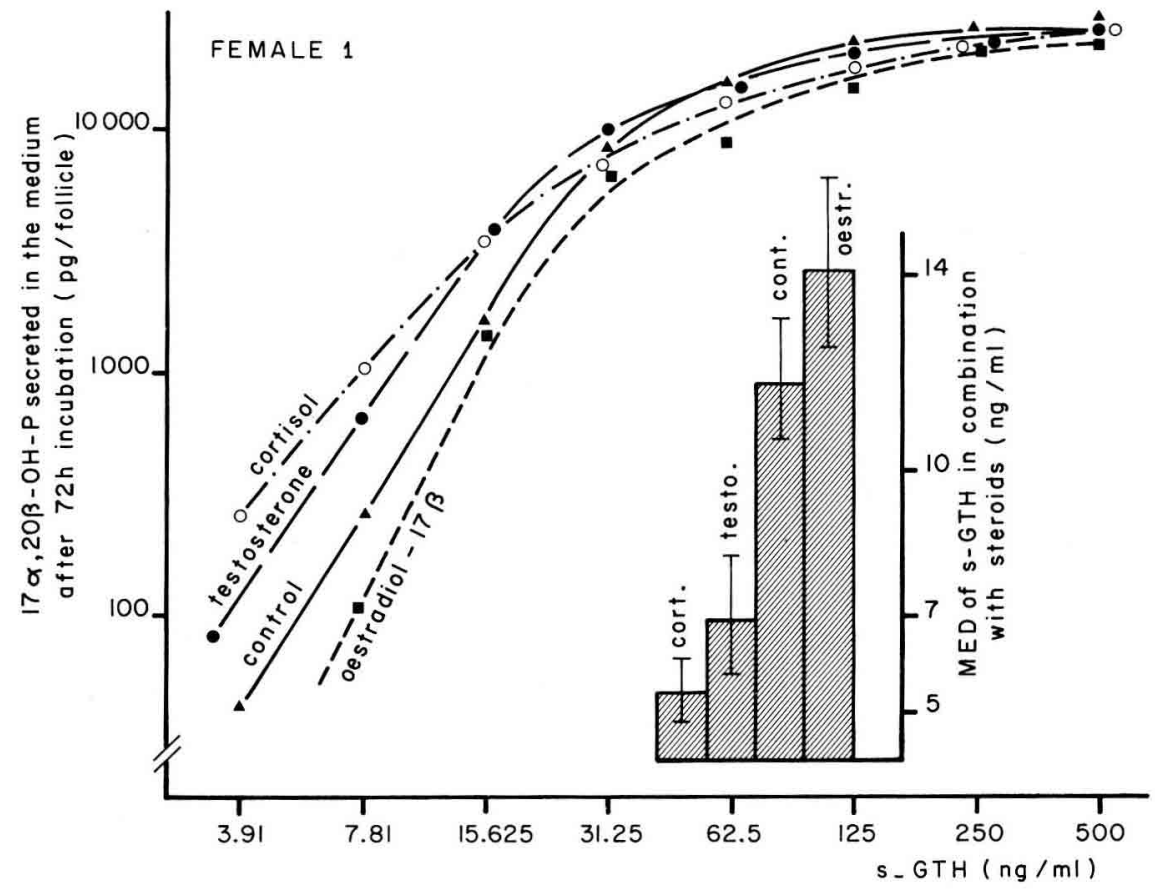

FIG. 2. - Same as figure 1 after 72-h incubation. The histogram on the right represents the median efficient dose (MED) of s-GtH for oocyte maturation (morphological criterion) in the presence of cortisol, testosterone, oestradiol or in the control (female 1).

These data fit well with the maturational response of the oocytes incubated within the follicles, as shown by the MED of s-GtH for oocyte maturation in the presence of steroids (fig. 2) ; this response was significantly lowered by cortisol and testosterone and increased by oestradiol (but not significantly in female 1).

In the experiment run with female 2 (fig. 3, table 2), the effect of oestradiol and testosterone was confirmed in the same experimental conditions. The inhibitory effect of oestradiol on $17 \alpha, 20 \beta-\mathrm{OH}-\mathrm{P}$ secretion was already significant

TABLE 2

(Female 2) : Same legend as Table 1.

Concentration of s-GtH (ng/ml)

3.91

31.25

125

500

Oestradiol-17 $\beta$

$48 \mathrm{~h}$

inhibition $\left({ }^{* *}\right)$

inhibition $\left({ }^{*}\right)$

$72 \mathrm{~h}$ inhibition $\left(^{* *}\right)$

Testosterone

\begin{tabular}{lll}
$48 \mathrm{~h}$ & stimulation $(*)$ & $\mathrm{NS}$ \\
\hline $72 \mathrm{~h}$ & stimulation $\left({ }^{*}\right)$ & $\mathrm{NS}$
\end{tabular}


after $48 \mathrm{~h}$ and became very highly significant after $72 \mathrm{~h}$, whatever the dose of s$\mathrm{GtH}$; this effect corresponded to a significant increase in the MED of s-GtH for oocyte maturation. The effect of testosterone upon the MED of $\mathrm{s}-\mathrm{GtH}$ was not significant in female 2 , but a stimulatory effect could be observed on $17 \alpha, 20 \beta$ $\mathrm{OH}-\mathrm{P}$ secretion in response to the lower doses of $\mathrm{GtH}$ (up to $31.25 \mathrm{ng} / \mathrm{ml}$ ).

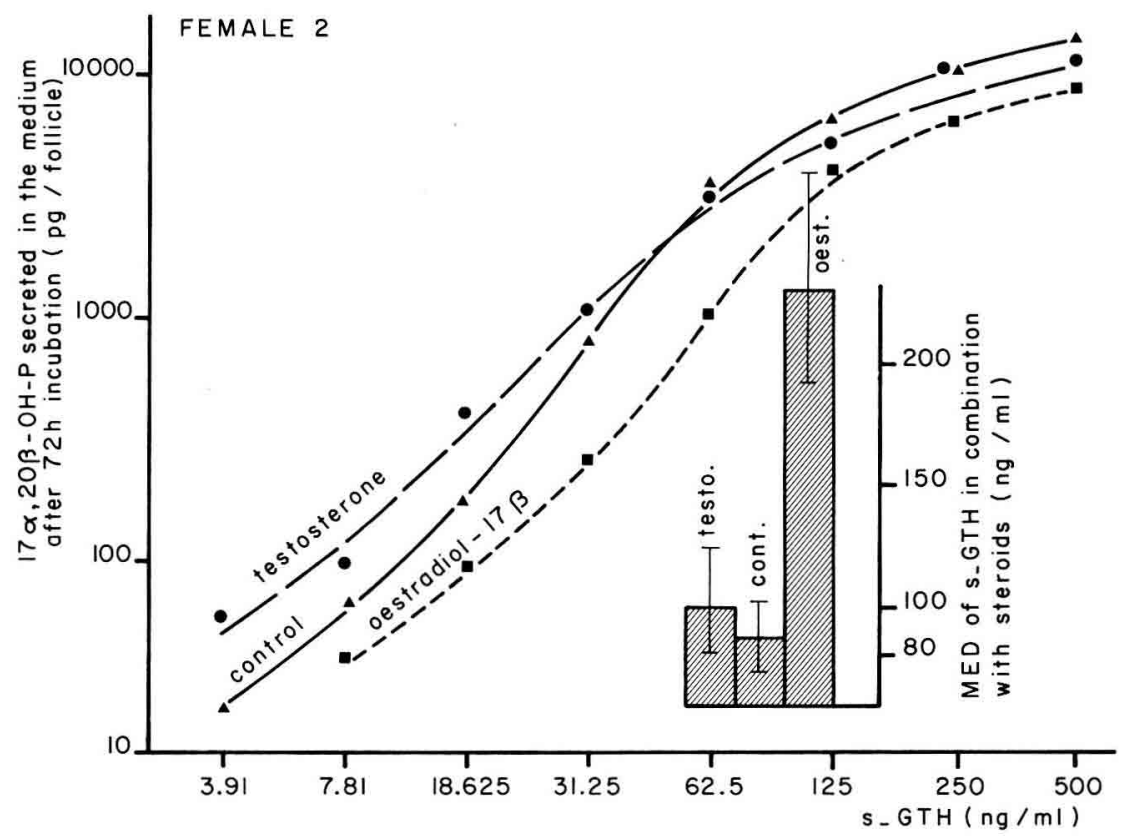

FIG. 3. - Same as figure 2 but concerns female 2.

\section{Discussion.}

The reality of a physiological role for oestradiol, testosterone or cortisol in vivo, as suggested by our results, could be questioned, considering the dose applied in vitro $(1 \mu \mathrm{g} / \mathrm{ml})$ which is far higher than the blood levels. As no data were available concerning steroid levels and availability in situ within the ovarian follicle in fish, this dose was chosen because it was expected to be high enough to ensure good penetration through the follicular envelopes in conditions of static incubation in vitro without perfusion. Besides, each of the considered steroids had already been shown to be ineffectual alone in inducing intrafollicular oocyte maturation at that level (Jalabert et al., 1973). In mammals, androgens and oestrogens are found in the follicular fluid at much higher levels than in the plasma (Chang et al., 1976 ; Eiler and Nalbandov, 1977; Fortune and Hansel, 1979). In amphibians, the high level of testosterone found in Xenopus ovaries treated by GtH in vitro led Fortune and Tsang (1981) to the hypothesis that endogenous testosterone could trigger meiotic maturation in vitro. Moreover, we 
know that cortisol and oestradiol can significantly modify the MED of s-GtH for intrafollicular oocyte maturation in trout even at a concentration of $40 \mathrm{ng} / \mathrm{ml}$ (Jalabert and Fostier, 1983) which is close to plasma levels during vitellogenesis (Billard et al., 1978).

It can be hypothesized that the amount of $17 \alpha, 20 \beta-\mathrm{OH}-\mathrm{P}$ measured in the incubation medium after 48 and $72 \mathrm{~h}$ was related to the total amount actually synthesized by the follicle. On the one hand the possibility that metabolic transformations of $17 \alpha, 20 \beta-\mathrm{OH}-\mathrm{P}$ could occur during incubation cannot be ruled out (Suzuki, Tamaoki and Hirose, 1981), but this is probably a minor phenomenon, if any, considering the kinetics of $17 \alpha, 20 \beta-\mathrm{OH}-\mathrm{P}$ accumulation already observed in the incubation medium after s-GtH stimulation (Fostier et al., 1981 ) ; on the other hand, most of the amount of $17 \alpha, 20 \beta-\mathrm{OH}-\mathrm{P}$ synthesized in vitro after $\mathrm{s}-\mathrm{GtH}$ stimulation has been shown to be released into the surrounding medium (Fostier and Jalabert, 1983).

The above arguments lead us to conclude from the present data that oestradiol, testosterone and cortisol are actually able to modulate the secretion of $17 \alpha, 20 \beta-\mathrm{OH}-\mathrm{P}$ by trout ovarian follicles in response to $\mathrm{GtH}$. This would explain why these steroids modulate, in the same way, the morphological maturational response to $\mathrm{GtH}$ of oocytes incubated within their follicle (Jalabert, 1975). Moreover, in the present experiment where overall follicular sensitivities (evaluated by the MED of $\mathrm{s}-\mathrm{GtH}$ for intrafollicular oocyte maturation) are very different in the two females, it is crucial to note that the significance of the modulatory ability of any steroid on the MED of maturational s-GtH is strictly related to the significance of the modulatory effect of the same steroid on $17 \alpha$, $20 \beta-\mathrm{OH}-\mathrm{P}$ secretion in response to a dose of $\mathrm{s}-\mathrm{GtH}$ in the range of the control MED. This observation supports our hypothesis that oestradiol and testosterone, which do not interfere with $17 \alpha, 20 \beta-\mathrm{OH}-\mathrm{P}$ maturational action in vitro, act essentially at the follicular level in trout. In contrast, some observations in other fishes and amphibians favour the hypothesis that the oocyte itself is a target for oestradiol or testosterone which would interfere directly with the maturationinducing steroid (MIS) at the oocyte level. This appears to be the case in catfish, where oestradiol or testosterone inhibits oocyte maturation induced by cortisol, the hypothetical MIS (Sundararaj, Goswami and Lamba, 1979). and in such amphibians as Rana pipiens where progesterone-induced germinal vesicle breakdown (GVBD) can be inhibited by oestradiol even in denuded oocytes (Lin and Schuetz, 1983). One cortisol action site also appears to be located at the follicular level, but the possibility remains of a synergic action with $17 \alpha, 20 \beta-\mathrm{OH}-\mathrm{P}$ at the oocyte level. Such a synergic action between $17 \alpha, 20 \beta-\mathrm{OH}-\mathrm{P}$ and deoxycorticosterone at that level in the amago salmon has also been suggested (Young, Kagawa and Nagahama, 1982).

OEstradiol-17 $\beta$ generally appears to play an inhibitory role in the regulation of oocyte meiotic maturation in different classes of vertebrates: mammals (Racowsky and McGauchey, 1982) amphibians (Schuetz, 1972 ; Baulieu et al., 1978 ; Lin and Schuetz, 1983) with a contradictory result in Xenopus laevis (Hanocq-Quertier and Baltus, 1981) and fish (Jalabert, 1975 ; Sundararaj, Goswami and Lamba, 1979 ; Theofan, 1981). In Rana pipiens (Spiegel, Jones and 
Snyder, 1978) and in the brook trout, Salvelinus fontinalis (Theofan, 1981), œstradiol inhibits $3 \beta$-hydroxysteroid dehydrogenase. The physiological role of such an inhibitory œstradiol-17 $\beta$ effect on $\mathrm{GtH}$-induced progestin secretion would be to avoid premature meiotic maturation before completion of vitellogenesis when œstradiol- $17 \beta$ levels are high.

Testosterone induces maturation in vitro in intrafollicular oocytes of the medaka when used alone (Hirose, 1972) or shows positive synergy with GtH in trout (Jalabert, 1975). However, it was found to inhibit oocyte intrafollicular maturation induced by either cortisol, LH or pregnenolone in the catfish, Heteropneustes fossilis, exactly like œstradiol (Sundararaj, Goswami and Lamba, 1979). Such a contradiction might result from differences in aromatase activity which could depend on the ovarian stage and/or the species.

The positive action of cortisol upon $\mathrm{GtH}$-induced $17 \alpha, 20 \beta-\mathrm{OH}-\mathrm{P}$ secretion in trout in the present study can be compared to some extent to the positive synergic effect of glucocorticoids on the FSH-stimulated production of progesterone by rat granulosa cells in vitro (Adashi, Jones and Hsueh, 1981).

In conclusion, our data lead to the assumption that the modulatory effect of oestradiol, testosterone or cortisol an $\mathrm{GtH}$-induced $17 \alpha, 20 \beta-\mathrm{OH}-\mathrm{P}$ secretion in vitro in the present experiment is probably representative of the physiological regulation occuring in vivo. Finally, such a regulatory role for these steroids is coherent with our present knowledge of the profiles of their secretion in vitro by s-GtH-stimulated follicles (Fostier et al., 1981 ; Zohar, Breton and Fostier, 1982), and of their plasma profiles around spawning time. Thus, preovulatory decrease of the œstradiol level (Fostier et al., 1978), transitory rise in testosterone level (Fostier and Jalabert, 1982) and overall increase of corticosteroids (Pickering and Christie, 1981) certainly contribute to the progressively increased ability of the follicle to secrete $17 \alpha, 20 \beta-\mathrm{OH}-\mathrm{P}$ in response to $\mathrm{GtH}$.

Reçu en juillet 1983.

Accepté en novembre 1983.

Résumé. Effet modulateur de l'cestradiol-173, de la testostérone ou du cortisol in vitro sur

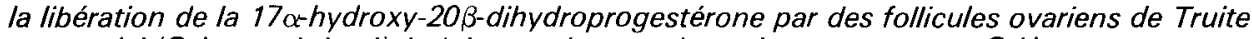
arc-en-ciel (Salmo gairdneri) induite par la gonadotropine maturante s-GtH.

L'effet de l'adjonction au milieu d'incubation d'cestradiol-17 $\beta$, de testostérone ou de cortisol $(1 \mu \mathrm{g} / \mathrm{ml})$ sur la libération de $17 \alpha, 20 \beta-\mathrm{OH}-\mathrm{P}$ in vitro par des follicules ovariens de Truite (contenant initialement des ovocytes au stade de la vésicule germinative en position subpériphérique) a été étudié afin de préciser par quel mécanisme ces stéroïdes sont capables de moduler l'efficacité de la GtH sur la maturation ovocytaire intrafolliculaire in vitro.

L'œstradiol-17 $\beta$ s'est révélé capable de déprimer la sécrétion de $17 \alpha, 20 \beta-\mathrm{OH}-\mathrm{P}$ par les follicules des deux femelles restées, même lorsque l'augmentation de la dose de GtH efficace à $50 \%\left(D_{50}\right.$ ou MED) pour induire la maturation ovocytaire (critères morphologiques) n'était pas significative chez l'une des femelles. Cet effet dépresseur est observé pour toutes les doses de $\mathrm{GtH}$ essayées (de 3,91 à $500 \mathrm{ng} / \mathrm{ml}$ ).

La testostérone et le cortisol ont stimulé de façon significative la sécrétion de $17 \alpha, 20 \beta$ $\mathrm{OH}-\mathrm{P}$, mais seulement pour les doses de $\mathrm{GtH}$ inférieures à $31,2 \mathrm{ng} / \mathrm{ml}$, alors que la diminution de $\mathrm{DE}_{50}$ de la $\mathrm{GtH}$ pour la maturation ovocytaire n'était pas toujours significative. 
Ces résultats apparaissent comme représentatifs de la situation physiologique, compte tenu des connaissances récentes sur l'évolution des profils plasmatiques des stéroïdes considérés pendant la période périoculatoire chez la Truite.

\section{References}

ADASHI E. Y., JONES P. B. C., HSUEH A. J. W., 1981. Synergistic effect of glucocorticoïds on the stimulation of progesterone production by follicle-stimulating hormone in cultured rat granulosa cells. Endocrinology, 109, 1888-1894.

BAULIEU E. E., GODEAU F., SCHORDERET M., SCHORDERET-SLATKINE S., 1978. Steroidinduced meiotic division in Xenopus laevis oocytes : surface and calcium. 'Nature, 275, 593598.

BILLARD R., BRETON B., FOSTIER A., JALABERT B., WEIL C., 1978. Endocrine control of the teleost reproductive cycle and its relation to external factors : salmonid and cyprinid models, 37-48. In GAILLAR P. J., BOER H. H. Comparative endocrinology. Elsevier/NorthHolland biomed. Press, Amsterdam.

BRETON B., PRUNET P., REINAUD P., 1978. Sexual differences in salmon gonadotropin. Ann. Biol. anim. Bioch. Biophys., 18, 759-765.

CHANG S. C. S., JONES J. D., ELLEFSON R. D., RYAN R. J., 1976. The porcine ovarian follicle : I. Selected chemical analysis of follicular fluid at different developmental stages. Biol. Reprod., 15, 321-328.

DUFFEY R. G., GOETZ F. W., 1980. The in vitro effects of $17 \alpha$-hydroxy-20 $\beta$-dihydroprogesterone on germinal vesicle breakdown in brook trout (Salvelinus fontinalis) oocytes. Gen. comp. Endocrin., 41, 563-565.

EILER H., NALBANDON A. V., 1977. Sex steroids in follicular fluid and blood plasma during the estrous cycle of pigs. Endocrinology, 100, 331-338.

FORTUNE J. E., HANSEL W., 1979. The effects of $17 \beta$-estradiol on progesterone secretion by bovine theca and granulosa cells. Endocrinology, 104, 1834-1838.

FORTUNE J. E., TSANG P. C., 1981. Production of androgen and estradiol-17 $\beta$ by Xenopus ovaries treated with gonadotropins in vitro. Gen. comp. Endocr., 43, 234-242.

FOSTIER A., JALABERT B., 1982. Physiological basis of practical means to induce ovulation in fish, 164-173. PURDOC, Wageningen. Proc. int. Symp. Reprod. Physiol. Fish.

FOSTIER A., JALABERT B., 1983. Mise au point d'un dosage biologique sensible pour la mesure des activités gonadotropes hypophysaires. Reprod. Nutr. Develop., (in press).

FOSTIER A., JALABERT B., CAMPBELL C., TEROUI M., BRETON B., 1981. Cinétique de libération in vitro de $17 \alpha$-hydroxy-20 $\beta$-dihydroprogesterone par des follicules de Truite arc-enciel Salmo gairdneriï. C. R. Acad. Sci. Paris, Sér. D. 292, 777-780.

FOSTIER A., JALABERT B., TEROUI M., 1973. Action prédominante d'un dérivé hydroxylé de la progestérone sur la maturation in vitro des ovocytes de la Truite arc-en-ciel, Salmo gairdnerii. C. R. Acad. Sci. Paris, Sér. D, 277, 421-424.

FOSTIER A., WEIL C., TERQUI M., BRETON B., JALABERT B., 1978. Plasma estradiol-17 $\beta$ and gonadotropin during ovulation in rainbow trout (Salmo gairdneri R.). Ann. Biol. anim. Bioch. Biophys., 18, 929-936.

GOETZ F. W., 1983. Hormonal control of oocyte final maturation and ovulation in fishes. In : Fish physiology, Vol. IX B, chap. 3 (W. S. HOAR and D. J. RANDALL). Acad. Press, N. Y. (in press).

HANOCO-QUERTIER J., BALTUS E., 1981. Induction of meiosis of Xenopus laevis oocytes by mianserine. Gam. Res., 4, 49-56.

HIROSE K., 1972. Biological study on ovulation in vitro of fish. IV. Induction of in vitro ovulation in Oryzias latipes oocyte using steroids. Bull. jap. Soc. Sci. Fish., 5, 457-461.

JALABERT B., 1975. Modulation par différents stéroïdes non maturants de l'efficacité de la $17 \beta$-hydroxy-20 $\beta$-dihydroprogestérone ou d'un extrait gonadotrope sur la maturation intrafolliculaire in vitro des ovocytes de la Truite arc-en-ciel Salmo gairdnerii. C. R. Acad. Sci. Paris, Sér. D, 281, 811-814.

JALABERT B., 1976. In vitro oocyte maturation and ovulation in rainbow trout (Salmo gairdneri), northern pike (Esox lucius), and goldfish /Carassius auratus). J. Fish. Res. Bd. Can., 33, 974-988. 
JALABERT B., BRETON B., BILLARD R., 1974. Dosage biologique des hormones gonadotropes de poissons par le test de maturation in vitro des ovocytes de Truite. Ann. Biol. anim. Bioch. Biophys., 14, 217-228.

JALABERT B., BRY C., BRETON B., CAMPBELL C., 1976. Action de la 17 $\alpha$-hydroxy-20 $\beta$ dihydroprogestérone et de la progestérone sur la maturation et l'ovulation in vivo et sur le niveau d'hormone gonadotrope plasmatique $\mathrm{t}-\mathrm{GtH}$ chez la Truite arc-en-ciel Salmo gairdnerii. C. R. Acad. Sci. Paris, Sér. D, 283, 1205-1208.

JALABERT B., BRY C., SZÖLLÖSI D., FOSTIER A., 1973. Etude comparée de I'action des hormones hypophysaires et stérö̈des sur la maturation in vitro des ovocytes de la Truite et du Carassin. Ann. Biol. anim. Bioch. Biophys., 13, 59-71.

JALABERT B., FOSTIER A., 1983. Evolution of the follicular of the follicular sensitivity in vitro to maturation-inducing hormones at the end of vitellogenesis in rainbow trout Salmo gairdnerii ; role of oestradiol-17\%. Aquaculture (in press).

LIN Y. W. P., SCHUETZ A. W., 1983. In vitro estrogen modulation of pituitary and progesteroneinduced oocyte maturation in Rana pipiens. J. exp. Zool., 226, 281-291.

NAGAHAMA Y., KAGAWA H., TASHIRO F., 1980. The in vitro effects of various gonadotropins and steroid hormones on oocyte maturation in amago salmon Oncorhynchus rhodurus and rainbow trout Salmo gairdnerii. Bull. jap. Soc. sci. Fish., 46, 1097-1102.

PICKERING A. D., CHRISTIE P., 1981. Changes in the concentrations of plasma cortisol and thyroxine during sexual maturation of the hatchery-reared brown trout, Salmo trutta L. Gen. comp. Endocr., 44, 487-496.

RACOWSKY C., McGAUCHEY R. W., 1982. In the absence of protein, estradiol suppresses meiosis of porcine oocytes in vitro. J. exp. Zool., 224, 103-110.

SCHUETZ A. W., 1972. Estrogens and ovarian follicular functions in Rana pipiens. Gen. comp. Endocr., 18, 32-36.

SCOTT A. P., BAYNES S. M., 1982. Plasma levels of sex steroids in relation to ovulation and spermiation in rainbow trout (Salmo gairdmerii), 103-106. Proc. int. Symp. Reprod. Physiol. Fish, PUDOC Wageningen.

SCOTT A. P., SUMPTER J. P., HARDIMAN P. A., 1983. Hormone changes during ovulation in rainbow trout (Salmo gairdnerii R.). Gen. comp. Endocr., 49, 128-134.

SPIEGEL J., JONES E., SNYDER B. W., 1978. Estradiol-17 $\beta$ interference with meiotic maturation in Rana pipiens ovarian follicles : evidence for inhibition of $3 \beta$-hydroxy-steroid dehydrogenase. J. exp. Zool., 204, 187-192.

SUNDARARAJ B. I., GOSWAMI S. V., LAMBA V., 1979. Some aspects of oocyte maturation in catfish. J. Ster. Bioch, 11,701-707

SUZUKI K., NAGAHAWA Y., TAMAOKI B. 1., 1981. In vitro synthesis of an inducer for germinal vesicle breakdown of fish oocytes, $17 \alpha$-20 $\beta$-dihydroxy-4-pregnen-3-one by ovarian tissue preparation of amago salmon (Oncorhynchus rhodurus). Gen. comp. Endocr., 45, 533-535.

SUZUKI K., TAMAOKI B. I., HIROSE K., 1981. In vitro metabolism of 4-pregnenes in ovaries of a freshwater teleost, the ayu (Plecoglossus altive/is): production of $17 \alpha$-20 $\beta$-dihydroxy-4pregnen-3-one and its $5 \beta$-reduced metabolites, and activation of $3 \beta$ and $20 \beta$-hydroxy-steroid dehydrogenases by treatment with a fish gonadotropin. Gen. comp. Endocr, 45, 473-481.

THEOFAN G., 1981. The in vitro synthesis of final maturational steroids by ovaries of brook trout (Salvelinus fontinalis) and yellow perch (Perca flavescens), Ph. D. Doct. Diss. Univ. NotreDame, Ind. (USA), $137 \mathrm{pp.}$

YOUNG G., KAGAWA H., NAGAHAMA Y., 1982. Oocyte maturation in the amago salmon (Oncorhynchus rhodurus) : in vitro effects of salmon gonadotropin, steroids, and cyanoketone (an inhibitor of 3 $\beta$-hydroxy- $\Delta^{5}$-steroid dehydrogenase). J. exp. Zool., 224, 265-275.

ZOHAR Y., 1982. L'évolution de la pulsatilité et des cycles nycthéméraux de la sécrétion gonadotrope chez la Truite arc-en-ciel femelle, en relation avec le cycle sexuel annuel et par rapport à l'activité stéroidogène de l'ovaire. Th. Doct. Etat, Univ. Paris VI, 273 pp.

ZOHAR Y.; BRETON B., FOSTIER A., 1982. Gonadotropic function during the reproductive cycle of the female rainbow trout, Salmo gairdnerii, in relation to ovarian steroid secretion : in vivo and in vitro studies, 14-18. Proc. int. Symp. Reprod. Physiol. Fish., PUDOC Wageningen. 